\title{
Behaviour of Microbial Fuel Cell in a start-up phase
}

\section{Chikashi Sato*}

Department of Civil and Environmental Engineering, Idaho State University, $921 \mathrm{~S}$ 8th Avenue,

Stop 8060, Pocatello, ID 83209-8060, USA

E-mail: satochik@isu.edu

${ }^{*}$ Corresponding author

\section{Reymer G. Martinez}

Engineer II, Research Division, Bureau of Animal Industry,

Visayas Avenue, Dilliman,

1101 Quezon City, Philippines

E-mail: reymer71@yahoo.com

\section{Malcolm S. Shields}

Department of Biological Sciences, Idaho State University, $921 \mathrm{~S} 8$ th Avenue,

Stop 8007, Pocatello, ID 83209-8007, USA

E-mail: shiemalc@isu.edu

\section{Alba Perez-Gracia and Marco P. Schoen}

Measurement and Control Engineering Research Center, Idaho State University, $921 \mathrm{~S} 8$ th Avenue,

Stop 8060, Pocatello, ID 83209-8060, USA

E-mail: perealba@isu.edu

E-mail: schomarc@isu.edu

\begin{abstract}
A Single-Chamber Microbial Fuel Cell (SCMFC) was constructed and run in a sequential feed-and-draw cycle operation. Anaerobic mixed bacterial culture and wastewater obtained from a local municipal wastewater treatment plant were used as biocatalysts and media, respectively. The SCMFC behaviour in a start-up phase was examined using the electrical potential (voltage) profiles, and further evaluated for the electricity generation and organic reduction. The voltage profile, developed during the early stages of the SCMFC run, was characterised by two prominent voltage peaks, which gradually fused into one peak.
\end{abstract}

Keywords: anaerobic bacteria; biofilm; electric generation; MFC; microbial fuel cell; wastewater treatment. 
Reference to this paper should be made as follows: Sato, C., Martinez, R.G., Shields, M.S., Perez-Gracia, A. and Schoen, M.P. (xxxx) 'Behaviour of Microbial Fuel Cell in a start-up phase', Int. J. Environmental Engineering, Vol. x, No. x., pp.xxx-xxx.

Biographical notes: Chikashi Sato is currently a Professor of Environmental Engineering and a Director for the Environmental Science and Management program at Idaho State University, Pocatello, Idaho, USA. He received a PhD in Environmental Engineering from the University of Iowa and a Master's Degree in Environmental Health Engineering from the University of Kansas. He was an Assistant professor in the Civil and Environmental Engineering Department at Polytechnic University, New York, USA.

Reymer G. Martinez is currently with the Bureau of Animal Industry, Quezon City, Philippines, involved with research in biogas digester design. He received a BS in Agricultural Engineering from Gregorio Araneta University Foundation (currently, Dela Salle Araneta University), Manila, Philippines, and a MS in Environmental Engineering from Idaho State University, Idaho, USA. At the time this research was performed, Martinez was a graduate student under the Fulbright-Philippine Agriculture Scholarship Program (FPASP).

Malcolm S. Shields is currently a Professor of Microbiology at Idaho State University, Idaho, USA. His education includes a PhD in Bacterial Genetics and Physiology, University of Tennessee, an MS in Microbial Physiology from the University of Idaho, and a BS in Biology from Virginia Tech. He has held two post doctoral traineeships in the Department of Biochemistry and Molecular Biology at the Mayo Clinic Foundation with the USEPA. Regional Research Laboratory in Gulf Breeze, Florida, USA.

Alba Perez-Gracia received the BSc in Industrial Engineering from the Technical University of Catalonia in Barcelona, Spain, and the MSc. and PhD in Mechanical Engineering from the University of California at Irvine, where she also spent a year as a Postdoctoral Fellow. Previous to that, she worked in several companies as a design engineer and environmental planning engineer. She is currently an Assistant Professor at the College of Engineering at Idaho State University, Pocatello, Idaho, USA.

Marco P. Schoen received the BS and MS in Mechanical Engineering from the Swiss College of Engineering and from Widener University, respectively, and his $\mathrm{PhD}$ in Engineering Mechanics from Old Dominion University, Norfolk, Virginia, USA. He is currently an Associate Professor in Mechanical Engineering at Idaho State University, where he also serves as the Associate Director for the Measurement and Control Engineering Research Centre (MCERC).

\section{Introduction}

A Microbial Fuel Cell (MFC) is a device that converts chemical energy to electrical energy using microorganisms as catalysts. MFCs can be classified based on the basic design configuration or operating concepts: 
- dual-chamber cells vs. single-chamber cells

- mediator cells vs. mediator-free cells

- pure bacterial culture cells vs. mixed bacterial culture cells.

The minimum requirements for constructing a MFC are an anode, a cathode, an electrolyte medium that connects the two electrodes, an external circuit, fuel and microorganisms. A Dual-Chamber Microbial Fuel Cell (DCMFC), consisting of an anode and a cathode compartment, is the MFC prototype that has been studied most extensively. The DCMFC chambers are separated by a cation-specific membrane or a Proton-Exchange Membrane (PEM). The bacteria introduced into the anode chamber oxidise substrate (fuel) to generate electrons and protons. Some of the electrons generated are transferred to the anode, first, then follow the external circuit to the cathode. The protons migrate to the cathode chamber permeating through the PEM. On the surface of the cathode, electrons and protons are combined reducing oxygen to water (Gil et al., 2003).

The physiological state of a bacterial cell affects the production of electrical current. Generation of electricity is the consequence of oxidation of NADH and other coenzymes, which inadvertently rob growing cells having reduction potential needed for energy. Reproduction of bacteria consumes most of the electrons generated from oxidation of the substrate. Only a small fraction of the electrons generated are transferred to the anode, resulting in low net efficiencies of the electron transfer system. Various microorganisms have been examined in the MFC studies; for example, Proteous vulgaris (Delaney et al., 1984; Allen and Bennetto, 1993), Escherichia coli (Park and Zeikus, 2000, 2003; Kim et al., 2002), Shewanella putrefaciens (Kim et al., 2002), Geobacter sulfurreducens (Bond and Lovley, 2003) and Rhodoferax ferrireducens (Chaudhuri and Lovley, 2003). Certain iron reducing bacteria in sediment are associated with generation of electricity, including obligate anaerobes Geobacteraceae spp. (Bond et al., 2002) and facultative anaerobes Shewanella spp. (Logan et al., 2005). Shewanella putrefaciens, one of the most studied microorganisms in the MFC development, is facultative anaerobic bacteria that utilise water-insoluble Fe(III) as their electron acceptor (Kim et al., 1999a, 1999b, 1999c, 1999d, 2002).

The potential applications of the MFC technologies to economical power generation have led the researchers to the testing of a variety of organic compounds as a fuel source. Simple organic molecules such as glucose, lactate and acetate have been extensively examined as potential fuel (Delaney et al., 1984; Park and Zeikus, 2003; Bond and Lovley, 2003; Min and Logan, 2004). The major advantages of using these compounds include known electron-balance, and predictability and reproducibility of the results at least partly due to their known compositions, characteristics and degradation pathways. Organic matters in the form of carbohydrates are often found in industrial, agricultural and domestic wastes.

Understanding of bacterial ability to respire using various substrates is important in developing an effective MFC. In addition, knowledge of the mediators affecting the movement of electrons from bacteria to the electrode (anode) nearby is also of importance in enhancing the MFC performance. Bacteria transfer electrons to the anode through mediators either produced by the bacteria themselves or externally added, or they transfer electrons directly from cellular cytochromes (respiratory enzymes) to the electrode. Extracellular cytochromes (found in some metal respiring bacteria) could 
potentially shuttle electrons directly to the electrode without the need for an external mediator. For example, Shewanella putrefaciens can transfer electrons to the electrode without the help of a mediator (Kim et al., 2002). However, for most organisms, the direct transfer of electrons from microbial cells to the electrode is inefficient. Therefore, the electrochemical mediator is often necessary to enhance the MFC efficiency. Using the pure culture S. putrefaciens, Park and Zeikus (2002) found that the graphite anode with electron mediator produced current that was three orders of magnitude greater than did the anode without the mediator. The known mediators are thionine, methyl viologen and humic acid (Delaney et al., 1984). 2-Hydroxyl-1, 4-naphtoquinone, methylene blue, and neutral red have also been studied (Park and Zeikus, 2000, 2003; Kim et al., 2002). Delaney et al. (1984) examined the effectiveness of phenoxazine, phenothiazine, phenazine, indophenol and bipyridilium derivatives as redox mediators in the MFC with a reticulated vitreous carbon anode and a ferricyanide-Pt cathode. Ferricyanide, $\mathrm{Fe}(\mathrm{CN})_{6}{ }^{3-}$, has been known as an effective mediator that enhances the function of the cathode (Delaney et al., 1984). Although electro-active mediators can increase the rate or efficiency of electron transfer between the microorganisms to the electrodes, they have inherent drawbacks. The mediators are generally very toxic and expensive (Gil et al., 2003), are required at high concentrations to produce desirable effect (Park and Zeikus, 2000), and lack stability for a long-term use (Chaudhuri and Lovley, 2003).

The anode serves as the depository of electrons during the redox reaction; thus, the MFC ability to generate electricity is affected by the types (materials used) and surface area of the electrodes. Kim et al. (2002) showed that a mediator-less MFC with $S$. putrefaciens gave the relatively high Coulombic yield when the high concentration of bacteria and large surface area of the electrode were employed. Chaudhuri and Lovley (2003) reported that the increase in the anode surface area resulted in substantial increases in power production. On the other hand, Oh et al. (2004) deduced that the cathode performance affects an overall electricity production and directly affects the anode as well. The use of precious metals such as platinum and ruthenium in a form of foil or dust coating on the surface of cathode tends to increase electric potential. Oh et al. (2004) reported that power was decreased when the Pt-carbon cathode was replaced by the carbon cathode, whereas power was increased as the cathode surface area was increased.

The MFC performance has been evaluated in terms of potential $(\mathrm{mV})$, current $(\mathrm{mA})$, power $(\mathrm{mW})$, current density $\left(\mathrm{mA} / \mathrm{m}^{2}\right.$ of electrode surface area) or power density $\left(\mathrm{mW} / \mathrm{m}^{2}\right.$ of electrode surface area). Using a DCMFC with graphite felt anode and reticulated vitrious carbon cathode, and Proteus vulgaris, Allen and Bennetto (1993) obtained open-circuit voltages of approximately $700 \mathrm{mV}$. The DCMFC, equipped with graphite electrodes (both cathode and anode) and inoculated with Geobacter sulfurreducens, produced a current density of $65 \mathrm{~mA} / \mathrm{m}^{2}$ (Bond and Lovley, 2003). Chaudhuri and Lovley (2003) used a DCMFC having a cation-selective membrane. In the anode chamber, anaerobic bacteria Rhodoferax ferrireducens oxidised glucose to carbon dioxide, quantitatively transferring electrons to graphite electrodes without a need for an electron-shuttling mediator. The cathode chamber was sterile and contained potassium ferricyanide to enhance oxygen reduction by the cathode. The DCMFC with a load resistance of $1000 \Omega$, sustained a current density of ca. $31 \mathrm{~mA} / \mathrm{m}^{2}$. A mediator-less DCMFC containing wastewater microorganisms, generated electricity with the maximum current of $1.7 \mathrm{~mA}$, and simultaneously treated starch processing wastewater 
(Gil et al., 2003). Park and Zeikus (2003) obtained $14 \mathrm{~mA}$ current, $0.45 \mathrm{~V}$ potential, $1750 \mathrm{~mA} / \mathrm{m}^{2}$ current density and $788 \mathrm{~mW} / \mathrm{m}^{2}$ of power density using a $\mathrm{Mn}^{4+}$-graphite anode, a $\mathrm{Fe}^{3+}$-graphite cathode, and sewage sludge as biocatalyst. Logan et al. (2005) obtained a power density of $39 \mathrm{~mW} / \mathrm{m}^{2}$ using cysteine as oxygen scavenger in the DCMFC inoculated with anaerobic marine sediment (predominantly Shewanella spp.). In a study with $S$. cerevisiae during the log-growth phase by Videla and Arvia (1975), electric current was found to depend directly on the concentration of bacteria $(\mathrm{N})$, concentration of substrate glucose $(G)$, and surface area of electrode $(A)$. The relationship is given as

$$
I=k N G A
$$

where $k$ is the empirical rate constant.

The efficiency of the MFC is affected by a number of factors including

- the rate of oxidation of substrate by microorganisms

- the rate of subsequent electron transfer to the anode

- the internal resistance of the circuit

- the rate of proton transport to the cathode

- availability of electron acceptor $\left(\mathrm{O}_{2}\right)$ and other limitations for the rate of reduction at the cathode (Gil et al., 2003).

Several studies have been conducted to improve the MFC efficiency focusing on the design of the reactor and electrodes (Park and Zeikus, 2003; Liu and Logan, 2004; Liu et al., 2004), mediators and substrate combinations (Delaney et al., 1984) and biocatalysts (Delaney et al., 1984). Furthermore, studies have been performed to identify a suitable bacteria-media-mediator combination (Park and Zeikus, 2000; Delaney et al., 1984).

A Single-Chamber Microbial Fuel Cell (SCMFC) is of particular interest in the present study because a PEM (expensive) and an external mediator (often toxic and unstable) can be eliminated from the fuel cell design. Liu and Logan (2004) compared the power outputs between the SCMFC and DCMFC using glucose as substrate. In their study, the maximum power density of $262 \pm 10 \mathrm{~mW} / \mathrm{m}^{2}$ with a PEM was increased to $494 \pm 21 \mathrm{~mW} / \mathrm{m}^{2}$ by removing the PEM. However, Coulombic efficiency decreased from $40 \%$ to $55 \%$ with the PEM to $9-12 \%$ without the PEM. In a mixed bacterial community, complete utilisation of heterogeneous organic matters is possible, while simultaneously converting chemical energy to electrical potential (Park and Zeikus, 2002).

In the past decade or so, a much clearer understanding of the MFCs has emerged. However, further studies are required to accomplish both sufficient power generation and effective wastewater treatment for practical applications. The specific objectives of this study are threefold:

- to examine the SCMFC behaviour in a start-up phase using electrical potential

- to demonstrate the effect of Dissolved Oxygen (DO) on the generation of electricity in the SCMFC

- to evaluate the SCMFC's start-up performance as a device that generates electricity, while removing organics in wastewater. 


\section{Experimental method}

The SCMFC reactor body was constructed using a single rectangular solid block of polycarbonate, which was core drilled and tapped (Figure 1). Flanged covers were fabricated to close the anode side, but a hole at the cathode side permits air to make contact with the platinum $(\mathrm{Pt})$ coated carbon cathode. Rubber gaskets were placed on each flanged end and secured by stainless steel screws. Two sampling ports were tapped at the top of the reactor body to permit removal and addition of a medium solution. The anode electrode is made with plain Toray carbon paper (E-Tek®) without catalyst and waterproofing, while the carbon cathode electrode is coated on one side with $0.5 \mathrm{mg} / \mathrm{cm}^{2} 20 \% \mathrm{Pt}$ and waterproofed (ELAT® V2.1, E-Tek). The fuel cell has the following specifications: volume of $20.5 \mathrm{~cm}^{3}$, inner diameter of $2.55 \mathrm{~cm}$, electrode surface area of $5.10 \mathrm{~cm}^{2}$ each and a ratio of the effective area to the reactor volume of $24.9 \mathrm{~m}^{2} / \mathrm{m}^{3}$. A liquid silver solder (CAIG Laboratories, USA) was applied between the electrode and a Pt wire. A section of the platinum wire $(0.55 \mathrm{~mm}$ diameter, $15 \mathrm{~cm}$ length) was bonded to the electrodes using epoxy glue. After the attachment was completely dried, both the cathode and anode electrodes were soaked in deionised water for $1 \mathrm{~h}$ before assembling the reactor. Connecting wires of the data acquisition module and the multimetre were snaked through an instrumentation access hole at the side of the incubator.

Figure 1 Schematic of single-chamber microbial fuel cell

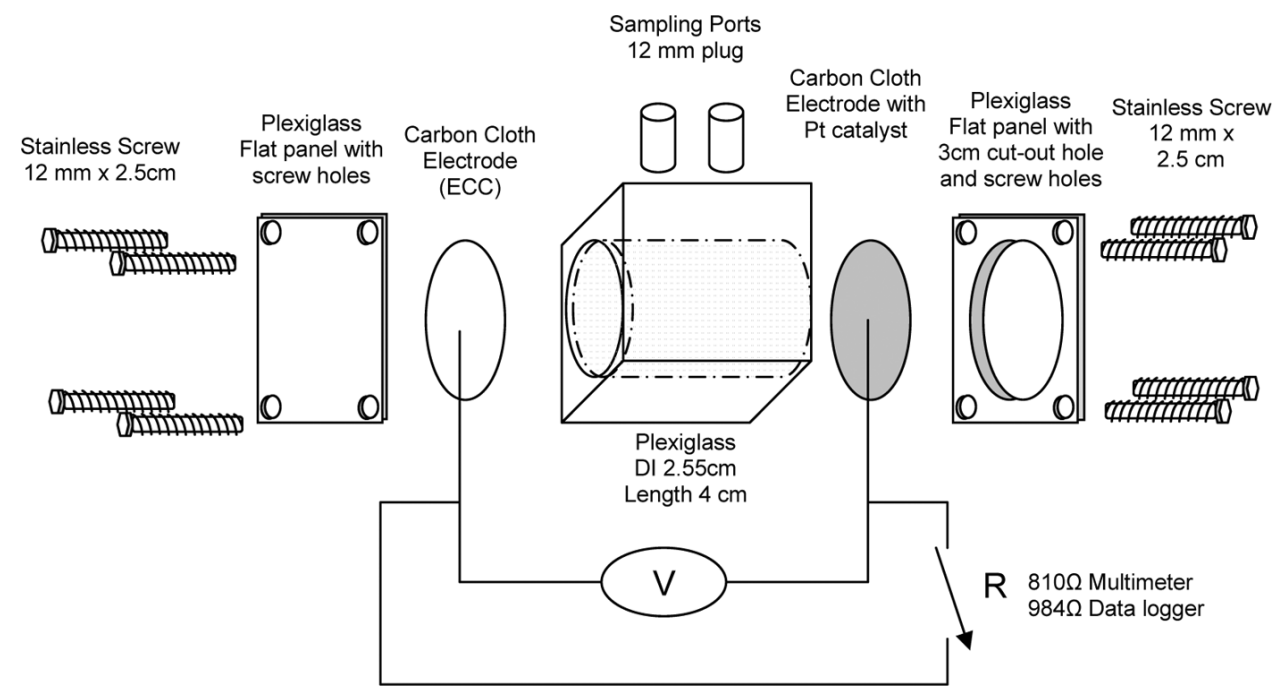

Indigenous mixed culture bacteria (biocatalyst) and wastewater (media) were obtained from the wastewater treatment plant of the city of Pocatello, Idaho, USA. Anaerobic sludge (as a source of mixed bacterial culture) was collected from the anaerobic digester, and wastewater was taken from the effluent of the primary clarifier. The wastewater was 
sterilised using an autoclave $\left(121^{\circ} \mathrm{C}, 20 \mathrm{~min}\right)$. The sterilised wastewater was buffered to $50-\mathrm{mM} \mathrm{K} \mathrm{K}_{2} \mathrm{HPO}_{4}, \mathrm{pH} 7.0$, in sealed glass culture bottles. Anaerobic bacterial communities were maintained in sealed screw-cap bottles containing the buffered wastewater at $32^{\circ} \mathrm{C}$. At the end of each month, $6.63 \mathrm{~mL}$ of the bacterial culture ( $5 \%$ of $126 \mathrm{~mL}$ passage bottle volume) was transferred to sterile, buffered wastewater.

To commence the SCMFC run, the reactor was filled with $10 \mathrm{~mL}$ of the sterilised wastewater and $10.5 \mathrm{~mL}$ of inoculum. The inoculation procedure was carried out inside an inflatable glove chamber filled with nitrogen $\left(\mathrm{N}_{2}\right)$ gas. The fuel cell and bottles containing the sterile wastewater feed were maintained in an incubator at $32^{\circ} \mathrm{C}$. The fuel cell was undisturbed for the duration of the inoculation and acclimation period ( 25 days) with the exception of daily addition of $\sim 3 \mathrm{~mL}$ of the feed wastewater every $24 \mathrm{~h}$ to compensate for evaporative loss of media through the cathode felt.

When sufficient microbial population was discerned (high turbidity 25 days after inoculation), a fill-and-draw operation was commenced. At the end of each cycle (usually $24 \mathrm{~h}$, unless otherwise stated), approximately $7.2 \mathrm{~mL}$ of supernatant was removed (note that $\sim 3 \mathrm{~mL}$ is lost daily due to evaporation), and approximately $10.2 \mathrm{~mL}$ of fresh sterile media was added to the fuel cell. The removal of the used media and addition of the fresh media were carried out inside the glove chamber. The harvested supernatants were stored at $4^{\circ} \mathrm{C}$ until analysis.

The waste strength was expressed using Chemical Oxygen Demand (COD). COD was analysed using the COD test kit vials containing a digestion solution (Hach Co., Loveland, CO, USA.). Before the COD analysis, all samples were filtered using a syringe driven $0.1 \mu \mathrm{m}$ filter unit (Millex ${ }^{\circledR}-\mathrm{VV}$, Millipore, Bedford, MA, USA). DO was analysed using a DO meter (Oxi 315i, Wissenchaftlich-Techniche Werkstätten GMbH \& Co KG [WTW], Weilheim, Germany), and $\mathrm{pH}$ was measured using a $\mathrm{pH}$ meter (Model $250 \mathrm{~A}$, Orion Research, Inc., Boston, MA, USA).

Electrical potential (voltage) produced by the SCMFC was continuously logged using a Data Acquisition System (DAS). The SCMFC-DAS is shown in Figure 2. A desktop computer was used to interface and automate the data gathering. The PC was equipped with National Instrument (NI) PCI Acquisition Board (PCI-6024E, National Instrument, Austin, TX, USA) and connection block (SCB-68, National Instrument, Austin, TX, USA). A $984 \Omega$ resistor was placed on the connection block. Virtual Instrumentation (VI) using LabVIEW $^{\circ}$ (version 8.0) was programmed to read voltage. A standalone digital multimeter (Model DM-7241, Goldstar, Korea) was also employed to take separate readings from the VI. An $810 \Omega$ resistor was bridged between the probes of the multimeter. Later in the experiment, another digital multimeter (Model 2105, Triplett, Korea) with PC interface was employed to back the NI DAS. This multimeter was attached to the resistor legs of the connection block. The separate measurements (from the VI and digital multimeter) showed a close match; thus, no further calibration of the instrument was performed. The multimeters (with a $810 \Omega$ resister) were used only for a quality control purpose to assure that the DAS was working correctly. All of the potential reading instrumentation was arranged in parallel circuit to achieve same current. 
Figure 2 Components of the MFC-DAS system (not scaled): (a) MFC;

(b) Shielded I/O connection block, SCB-68, NI; (c) Shielded 68-pin cable, NI and (d) PCI data acquisition board, PCI-6024E, NI (inside a PC) (Photo courtesy of National Instruments)

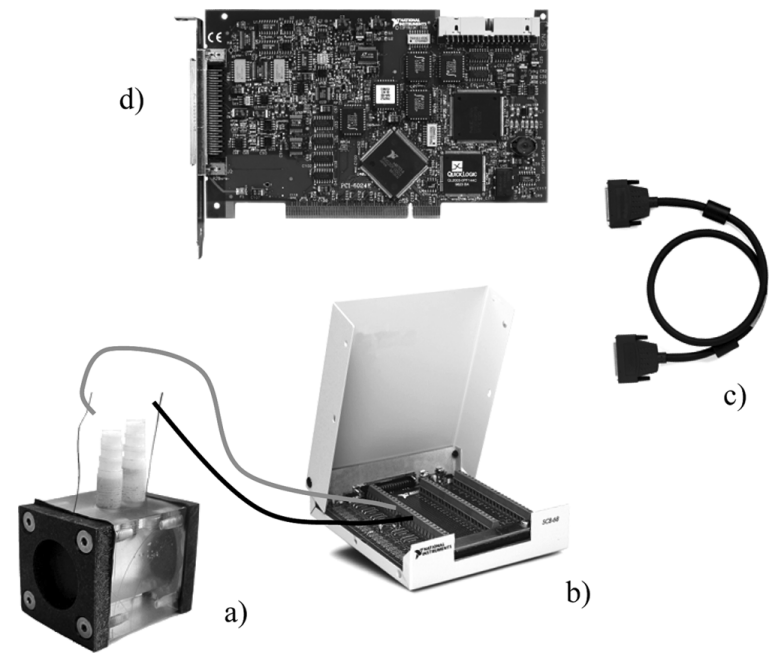

\section{Results and discussion}

\subsection{Initial start-up phase}

Mixed culture bacteria (anaerobic sludge) were transferred to a $200-\mathrm{mL}$ passage bottle containing sterilised wastewater (media). The inoculum was serially transferred every $\sim 30$ days to a passage bottle containing fresh media. After three passages (80 days after inoculation), an aliquot of $10.5 \mathrm{~mL}$ inoculum was transferred from the bottle to the fuel chamber (SCMFC). The remaining volume of the chamber was filled with sterile media. Initially, an attempt was made to grow bacteria and form biofilm on the surface of the electrodes, while compensating for media loss (due to diffusive evaporation from the cathode felt) by adding approximately $3 \mathrm{~mL}$ of media daily. During this period, no solution was removed from the chamber. Twenty five days after the inoculation, a fill-and-draw operation of the SCMFC was commenced (Day 1) in which $10.5 \mathrm{~mL}$ reactor culture was replaced by fresh media daily unless otherwise indicated.

Electrical potential in the initial stage (from Day 7 to Day 13) of the fill-and-draw run is shown in Figure 3. To determine current, a $984 \Omega$ resistance was created in parallel with the circuit. The added resistance resulted in a lower electrical potential than observed in previous runs without the added resistance. For all MFC runs, the DAS was set to collect potential readings at a rate of one reading per second; i.e., 60 data points per min. It is noteworthy that all 60 data points collected in 1 min are almost identical; i.e., error ranges generated using the 60 readings are smaller than the data points (diameter of a circle) presented. For clarity, the data were plotted every 15-20 min. Voltage readings revealed that there were two voltage peaks during one feeding cycle. For the purpose of comparison, the data from Day 8 and Day 13 are shown in Figures 4 and 5, respectively. A possible explanation for the formation of two-voltage peaks might be that there were two primary groups of bacteria in the fuel cell. One group 
consisted of suspended bacteria, which grew faster than the other group by consuming simple substrates (forming the first peak). The second group grew in aggregates, forming biofilm on the electrodes and reactor walls. The biofilm grew slowly utilising more complex molecules (forming the second peak). A comparison of voltage readings in Figure 3 reveals that the time interval between the two peaks became smaller as the feeding cycle progressed. It is expected that bacterial population increased with the feeding cycle; thus, the bacterial population on Day 13 (13th cycle) was higher than that on Day 8 (8th cycle). Presumably, over time, a stable community was established in the fuel cell, adapted to utilise the variety of organic substrates in the wastewater. It is speculated that, as the biofilm grew on the electrodes, the rate of substrate utilisation of the biofilm community exceeded that of the free living community. The result was the fusion of the two voltage potentials into a single peak as the faster responding biofilm community began to dominate the system and the bulk of organic oxidation metabolism. Allen and Bennetto (1993) found that Proteus vulgaris responded to substrate additions faster when immobilised than when freely suspended. Oh et al. (2004) reported that electricity was generated by attached bacteria on the electrode and not by suspended bacteria. Our study (data not shown) demonstrated that bacteria attached on the electrodes are primarily responsible for the generation of electricity and suspended bacteria have a minor role. The slow decline of voltage after the second peak in the Day 13 cycle is likely due to the rapid depletion of the more easily oxidised substrates leaving only more complex substrates and recycling of cellular debris.

Figure 3 Voltage potential during initial stage (Day 7-13) of SCMFC operation (with $984 \Omega$ external resistance)

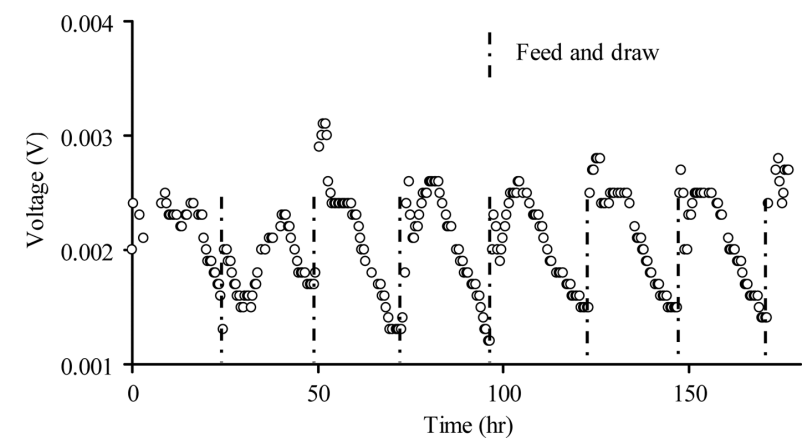

Figure 4 Twenty-four-hour cycle potential reading on the 8th day (33 days after SCMFC inoculation)

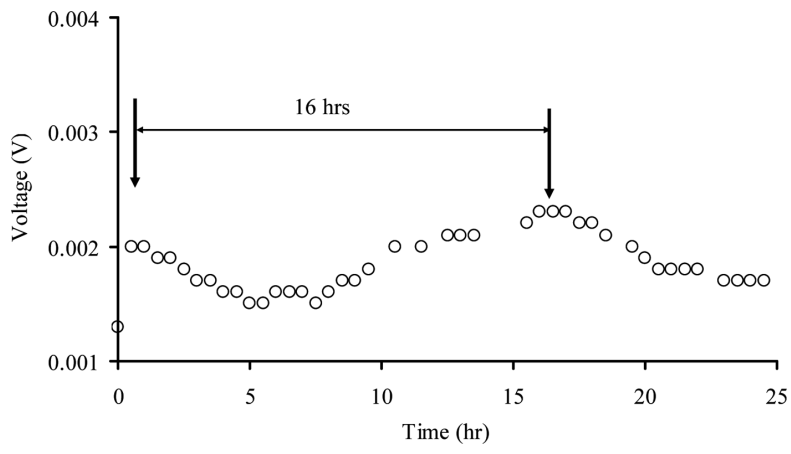


Figure 5 Twenty-four-hour potential reading on the 13th day (38 days after SCMFC inoculation)

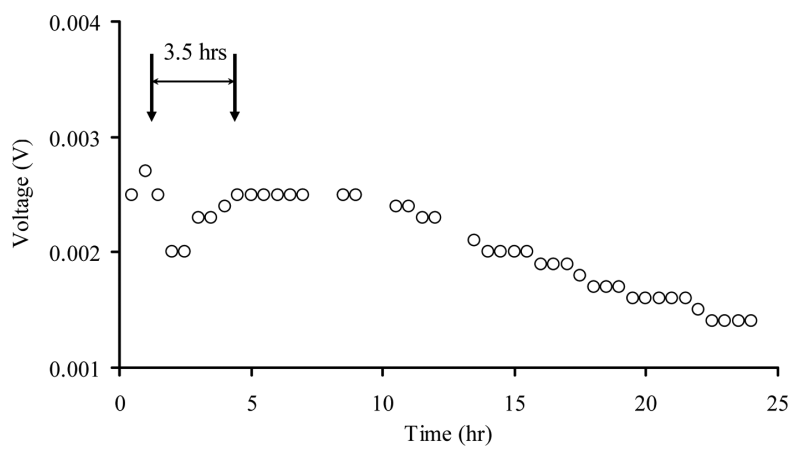

Further elaboration of the early microbial electrochemical stages based on representative plots (Day 10) are shown in Figure 6. In this figure, one feed-and-draw cycle is characterised by six inflection points seen in other cycles. Point 1 represents the initial conditions in which the bacterial population is metabolically less active and near starvation. At Point 1, substrates (i.e., sterilised wastewater) are added to the fuel cell. The conditions (e.g., added nutrients) at this point determine the bio-electrochemical profile that follows. The resting suspended bacteria begin active metabolism and oxidation of the readily available substrates. The height of the first peak (Point 2) depends on the bacterial activity (i.e., voltage) at Point 1 . In other words, with a greater net oxidative activity of bacteria at Point 1, the higher the voltage produced at Point 2. In the region between Points 2 and 3, electrical potential decreases because readily available substrates become limiting. In the region between Points 3 and 4, the bacterial community (perhaps different members and perhaps biofilm bacteria) begin utilising the more complex remaining substrates. The zone between Points 4 and 5 is the stage where the rate of electron production (primarily by the biofilm organisms) is balanced by cellular demand for electrons; thus, producing electricity at a constant rate. Point 5 is the point of entry to the starvation phase, where the number of live bacteria declines, and the demand for cellular reduction potential creates less excess electron flow. Dying bacteria contribute an increasing proportion of organic nutrients to the system. Accordingly, electric potential slowly declines. Point 6 is the end of the cycle (arbitrarily chosen by the investigators).

Figure 6 Twenty-four-hour potential reading on the 10th day (35 days after SCMFC inoculation). Filled circles represent reproducible inflection points in the voltage potential during one feeding cycle

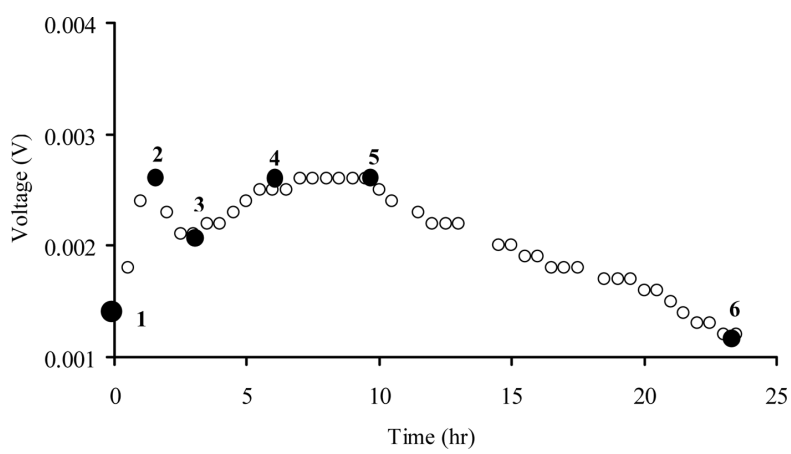


It is interesting to note that when the potential dropped below $1.3 \mathrm{mV}$ at the end of the previous cycle, the peak potential of the first peak was lower than that of the second peak (Figure 7). The result suggests that when the metabolic activity is reduced to a very low level (as indicated by the low voltage at Point 1), less electricity will be generated at Point 2 (1st peak) in response to the addition of substrates, but there is little impact on the potential at Points 4 and 5 (2nd peak). The result could reflect the more profound effect of starvation on the suspended bacterial population than the biofilm members. When bacteria are more active (as indicated by higher voltage) at the end of the previous cycle, voltage at Point 2 (1st peak) is higher than the region between Points 4 and 5 (2nd peak) in the following cycle. It appears that, if bacteria are more deeply starved in the previous cycle, more electricity will be generated by the biofilm-forming bacteria in the following cycle. This observation is supported by Kim et al. (2002) and Park and Zeikus (2000), who stated that the resting bacteria produced higher potential that correlated with elevated levels of cytochromes.

Figure 7 Effect of starvation of bacteria on generation of electricity in the SCMFC (Day 10-12)

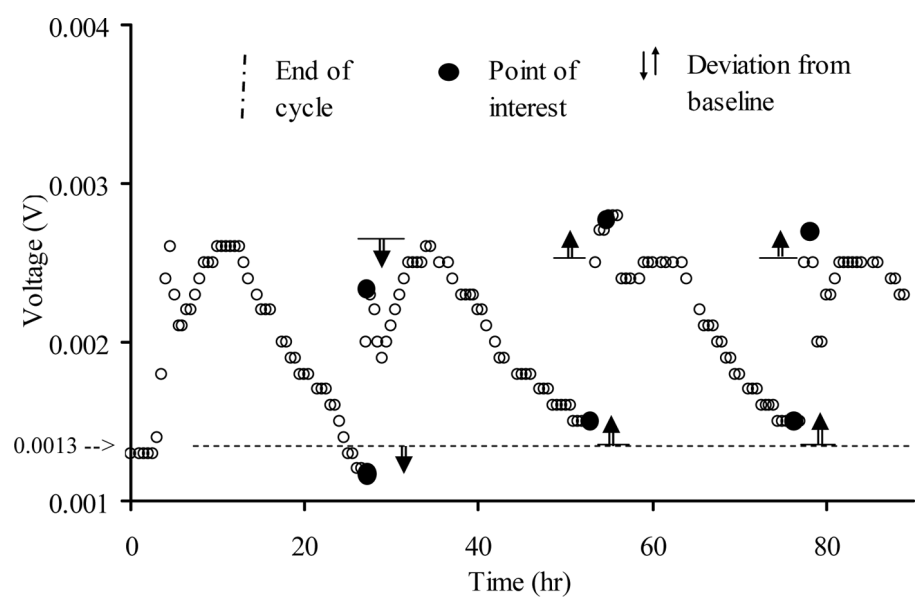

\subsection{Effect of Dissolved Oxygen on electric generation}

Electric generation is also affected by chemical conditions, particularly since oxygen molecules are necessarily present at the cathode. For the SCMFC with an air cathode, oxygen intrusion is especially detrimental to electric generation since it competes as an electron acceptor with the anode. Such a shift to aerobic metabolism may result in increased organic removal (Min and Logan, 2004; Liu et al., 2004). To determine the effect of DO on the SCMFC performance, the fuel cell was run with wastewater before and after nitrogen $\left(\mathrm{N}_{2}\right)$ gas purging before feeding the reactor. It is expected that the $\mathrm{N}_{2}$ purging will strip much of the DO from the wastewater, keeping the fuel cell more anoxic or anaerobic during batch feeding and liquid replenishment. Figure 8 shows six feed-and-draw cycle data (Day 17-25). In the first three cycles, the fuel cell was fed purged wastewater $\left(\mathrm{N}_{2}\right.$ for $\left.30 \mathrm{~min}\right)$ at 24,36 and $48 \mathrm{~h}$. In the following three cycles, wastewater purged for $120 \mathrm{~min}$, was fed at 26, 36 and $24 \mathrm{~h}$. The 120-min purging increased electric potential approximately from $2.5 \mathrm{mV}$ to $7 \mathrm{mV}$, whereas the 30 -min purging showed little impact on electric potential. The DO concentrations in the 
wastewater before and after the $120-\mathrm{min}_{2}$ purging were 2.1 and $0.6 \mathrm{mg} / \mathrm{L}$, respectively. The relatively high DO concentration in the unpurged wastewater indicates that the anode was probably poisoned by $\mathrm{O}_{2}$, at least until facultative bacteria reduced the introduced oxygen. Note that only one peak was developed in the succeeding cycles (after Day 23) as compared with the previous runs in which two peaks were developed. This may indicate that the biofilm-forming bacteria on the electrodes had become predominant organisms.

Figure 8 Effect of Dissolved Oxygen on electric generation (Day 17-25). The SCMFC (with a $984 \Omega$ resister) was fed wastewater purged with $\mathrm{N}_{2}$ gas for $30 \mathrm{~min}$ or $120 \mathrm{~min}$ at the times indicated

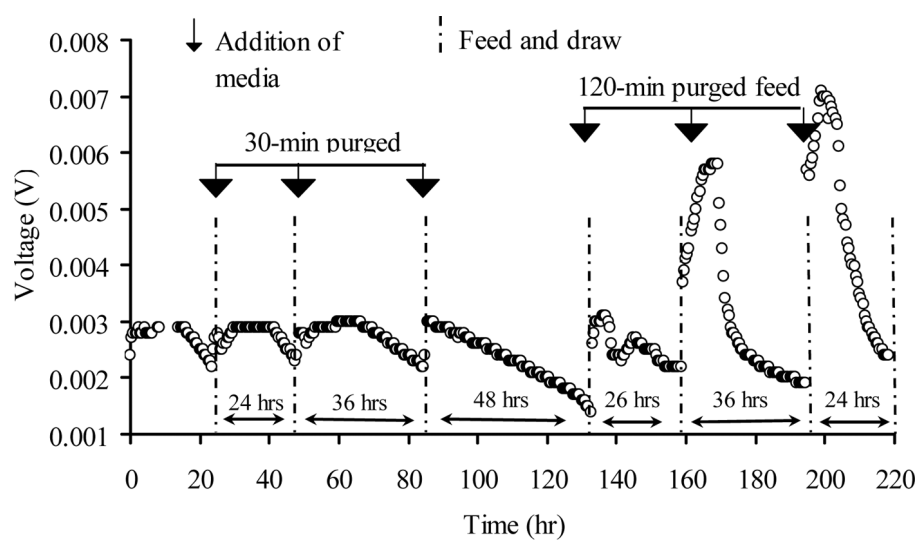

In the start-up phase, the SCMFC performance in terms of electric potential, current, power and power density is $2.5 \mathrm{mV}, 2.5 \times 10^{-3} \mathrm{~mA}, \quad 6.4 \times 10^{-6} \mathrm{~mW}$ and $1.3 \times 10^{-2} \mathrm{~mW} / \mathrm{m}^{2}$, respectively, with the unpurged wastewater. The fuel cell with the 30 -min purged wastewater produced $3.0 \mathrm{mV}, 3.0 \times 10^{-3} \mathrm{~mA}, 9.1 \times 10^{-6} \mathrm{~mW}$ and $1.8 \times 10^{-2} \mathrm{~mW} / \mathrm{m}^{2}$. With the 120 -min purged wastewater, the fuel cell produced $7.0 \mathrm{mV}$, $7.1 \times 10^{-3} \mathrm{~mA}, 5.0 \times 10^{-5} \mathrm{~mW}$ and $9.8 \times 10^{-2} \mathrm{~mW} / \mathrm{m}^{2}$. The enhanced MFC efficiency is most likely due to the reduced DO level in the feed wastewater. In Figure 9, it is clear that higher potentials are developed after removing DO from the feed wastewater. By day 61-62, the SCMFC generated up to $80 \mathrm{mV}$ of potential, $8.1 \times 10^{-2} \mathrm{~mA}$ of current, $6.5 \times 10^{-3} \mathrm{~mW}$ of power and $13 \mathrm{~mW} / \mathrm{m}^{2}$ of power density. Even with the $\mathrm{N}_{2}$ purging of wastewater, electrical potential obtained ranged from $1 \mathrm{mV}$ to $80 \mathrm{mV}$, which are considerably lower than those reported by other investigators (Allen and Bennetto, 1993; Bond and Lovley, 2003; Chaudhuri and Lovley, 2003; Park and Zeikus, 2003; Logan et al., 2005). It is noteworthy, however, that in the later stages under much higher substrate levels, electric potential as high as $300 \mathrm{mV}$ was generated (data not shown). In a DCMFC, a PEM theoretically acts as an oxygen barrier. In reality, however, oxygen molecules diffuse through the membrane (Liu and Logan, 2004). In the absence of the PEM, the flux of oxygen to the anode (anaerobic) side causes reduced efficiency of the anaerobic anode, retardation of anaerobic biofilm development, and substrate loss to aerobic metabolism (Liu and Logan, 2004). Liu and Logan (2004) reported that the rate of oxygen diffusion was $0.187 \mathrm{mg} / \mathrm{h}$ in their SCMFC which is similar to the one used in this study. At higher substrate concentrations, low DO levels may be maintained due to an increased number of facultative bacteria that can scavenge oxygen. 
Figure 9 Effect of Dissolved Oxygen on electric generation (Day 32-37). The SCMFC (with open circuit) was fed unpurged wastewater or purged with $\mathrm{N}_{2}$ gas for $120 \mathrm{~min}$ at the times indicated

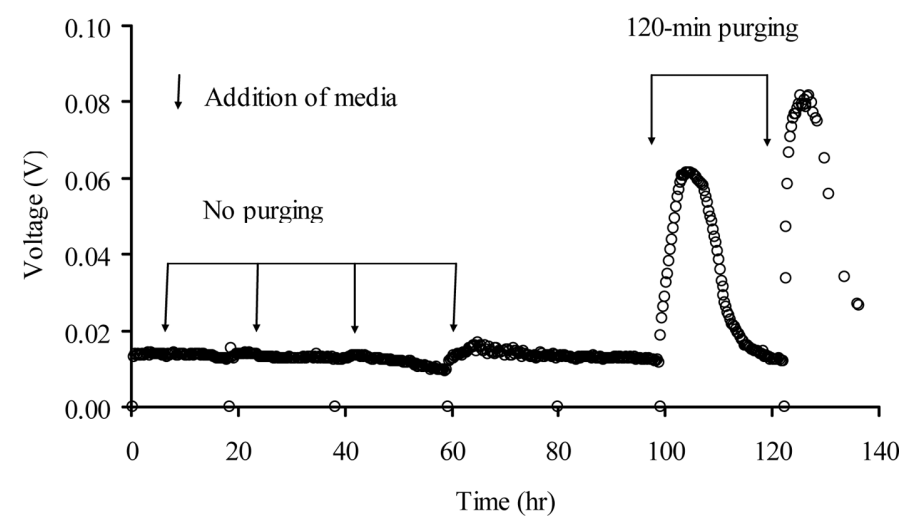

\subsection{Reduction of organics}

One of our primary interests is to develop a fuel cell that can generate electricity and simultaneously reduce organic levels of wastewater. Results from the COD measurements show that organic reduction is not significant in the SCMFC with both purged and unpurged wastewaters. The COD reduction with the unpurged wastewater ranges from $4.8 \%$ to $15.6 \%$ for an incubation period of $24 \mathrm{~h}$. With the 30 -min purged wastewater, the COD reduction increased with the duration of the cycle and was measured to be $7.7,17.0$ and $34.7 \%$ following 12,36 and $48 \mathrm{~h}$ of run time, respectively. Liu et al (2004) obtained $80 \%$ COD reduction in wastewater (primary clarifier effluent) and a power density of $26 \mathrm{~mW} / \mathrm{m}^{2}$, using an SCMFC having eight graphite anode electrodes and a single air cathode, operated in a continuous flow mode. Min and Logan (2004), using a Monod-type model to express power density as a function of wastewater strength (COD), found that the COD removal is a linear function of the logarithmic COD concentration. Kim et al. (1999a) stated that a mediator-free MFC cannot function with wastewater containing nitrate because nitrate reducing conditions inhibit synthesis of an effective electrochemical active surface structure. This is reasonable since nitrate is the best oxidiser after oxygen and could play a similar role in poisoning anodic reduction. The greater COD reduction can be achieved with longer reaction time (Min and Logan, 2004; Liu and Logan, 2004; Liu et al., 2004).

In our SCMFC, the small COD reduction can be attributed to factors such as limited nutrients, insufficient $\mathrm{pH}$ buffering capacity for optimal bacterial growth and accumulation of growth inhibiting byproducts or end products as a consequence of batch growth. To identify possible limiting anaerobic electron acceptors or micronutrients missing in the wastewater, an experiment was conducted with sterilised wastewater amended with inorganic nutrients and nitrate or sulphate as metabolic electron acceptors. The measured COD and percent COD reduction are presented in Table 1. Bottle 1 contained wastewater (autoclave-sterilised) and $\mathrm{pH}$ buffer $(50-\mathrm{mM}$ $\mathrm{K}_{2} \mathrm{HPO}_{4}$, pH 7.0). Bottle 2 contained wastewater, buffer and basal salt medium containing trace inorganic elements $(\mathrm{BSM}, 10 \mathrm{mM})$. The stock BSM consisted of: $\mathrm{K}_{2} \mathrm{HPO}_{4} 3 \mathrm{H}_{2} \mathrm{O}, 4.25 \mathrm{~g} ; \mathrm{NaH}_{2} \mathrm{PO}_{4} \mathrm{H}_{2} \mathrm{O}, 1.00 \mathrm{~g} ; \mathrm{NH}_{4} \mathrm{Cl}, 2.00 \mathrm{~g} ; \mathrm{MgSO}_{4} 7 \mathrm{H}_{2} \mathrm{O}, 0.20 \mathrm{~g}$; $\mathrm{FeSO}_{4} 7 \mathrm{H}_{2} \mathrm{O}, 0.012$ g; $\mathrm{MnSO}_{4} \mathrm{H}_{2} \mathrm{O}, 0.003 \mathrm{~g} ; \mathrm{ZnSO}_{4} 7 \mathrm{H}_{2} \mathrm{O}, 0.003$ g; $\mathrm{CoSO}_{4} 7 \mathrm{H}_{2} \mathrm{O}$, 
$0.001 \mathrm{~g}$ in $1 \mathrm{~L}$ of deionised water (Hareland et al., 1975). Bottle 3 contained wastewater, buffer, BSM and $\mathrm{Na}_{2} \mathrm{SO}_{4}$. Bottle 4 contained wastewater, buffer, $\mathrm{BSM}$ and $\mathrm{NH}_{4} \mathrm{NO}_{3}$. These bottles were inoculated with anaerobic sludge bacteria, and incubated for $24 \mathrm{~h}$ (Day $15-16$ ) at $32^{\circ} \mathrm{C}$. The greater COD reductions with Bottles 2, 3 and 4 indicate that the wastewater was nutrient limited for micronutrients, but not electron acceptors $\left(\mathrm{SO}_{4}{ }^{2-}\right.$ and $\left.\mathrm{NO}_{3}{ }^{-}\right)$. It appears that there are sufficient electron acceptors such as humic materials in the wastewater. Obviously, more detailed studies are necessary to make the fuel cell more efficient for the generation of electricity and reduction of organics. Although COD does not give specific levels of organics, the choice was made based on the smaller sample size, shorter analysis time and accuracy of the test, as compared with the five days Biochemical Oxygen Demand test $\left(\mathrm{BOD}_{5}\right)$. Since the COD removal rate is expected to be smaller than the BOD removal rate, the COD measurement is a more conservative assessment of organic reduction.

Table 1 COD test for nutrient deficiency in wastewater

\begin{tabular}{|c|c|c|c|c|}
\hline Bottle ID & 1 & 2 & 3 & 4 \\
\hline $50 \mathrm{mM} \mathrm{K}_{2} \mathrm{HPO}_{4}$ buffer & + & + & + & + \\
\hline $10 \mathrm{mM} \mathrm{BSM}^{\mathrm{a}}$ & & + & + & + \\
\hline $10 \mathrm{mM} \mathrm{SO}_{4}\left(\mathrm{Na}_{2} \mathrm{SO}_{4}\right)$ & & & + & \\
\hline $10 \mathrm{mM} \mathrm{NO}_{3}\left(\mathrm{NH}_{4} \mathrm{NO}_{3}\right)$ & & & & + \\
\hline Initial COD $\left(\mathrm{mg} / \mathrm{L}^{\mathrm{b}}\right)$ & 179 & 117 & 135 & 172 \\
\hline Final COD (mg/L $\left.{ }^{b}\right)$ & 167 & 75 & 96 & 116 \\
\hline COD reduction $(\%)$ & 7 & 36 & 29 & 33 \\
\hline
\end{tabular}

+Included.

${ }^{a}$ BSM, basal salt media containing inorganic trace elements and phosphorus.

${ }^{\mathrm{b}}$ Initial COD and final COD were measured on day 15 and 16, respectively.

\section{Conclusions}

A single-chamber microbial fuel cell was constructed, and its behaviour in the start-up phase was studied. In the early phase of the SCMFC runs, the fuel cell was characterised by the voltage profile consisting of two prominent peaks. It is hypothesised that the initial increase in voltage (1st peak) was formed by the metabolic activity of suspended bacteria that consume readily available substrates and the second peak was formed due to the activity of biofilm-forming bacteria that can utilise more complex organic molecules. The two peaks fused into one peak as the biofilm-forming bacteria became the predominant population that transfers electrons to the anode.

The SCMFC generated electricity ranging from $1 \mathrm{mV}$ to $7 \mathrm{mV}$ in the very early phase when microbial community was not established, and $60-80 \mathrm{mV}$ in the later phase. The fuel cell efficiency was improved by purging oxygen from feed wastewater with $\mathrm{N}_{2}$ gas, which lowered DO levels in the wastewater. In the later stages of the run (using wastewater purged with $\mathrm{N}_{2}$ gas for $120 \mathrm{~min}$ ), the fuel cell generated up to $80 \mathrm{mV}$ of potential, $8.1 \times 10^{-2} \mathrm{~mA}$ of current, $6.5 \times 10^{-3} \mathrm{~mW}$ of power and $13 \mathrm{~mW} / \mathrm{m}^{2}$ of power 
density. COD reduction up to $35 \%$ was obtained in a $24-\mathrm{h}$ period. The low organic reduction is likely due to limiting trace nutrients or phosphate.

\section{Outlook and further work}

Electric generation is dependent on a number of physical, chemical and biological factors. The physical parameters include, but not limited to, types of electrodes, sizes (surface areas) and configurations of a reaction chamber and electrodes. The chemical parameters include: $\mathrm{pH}$, temperature, redox potential (DO level), conductivity of the medium, and presence/absence of different mediators. Biological parameters may include different bacterial communities, population dynamics, stages of bacterial growth (lag, log, stationary and endogenous phases) and accompanying metabolic state, bacterial physical state (suspended vs. biofilm) and types of oxidisable substrates (electron donors). These provide ample areas for further research to improve the SCMFC performance for practical applications.

\section{Acknowledgements}

This research was partially supported by Grant No. S06-115 from the Graduate Student Research and Scholarship Committee of Idaho State University, Pocatello, Idaho. Kenyon Hart provided technical assistance on automated instrumentation and electronic equipment.

\section{References}

Allen, R.M. and Bennetto, H.P. (1993) 'Microbial fuel-cells: electricity production from carbohydrates', Appl. Biochem. Biotechnol., Vols. 39-40, pp.27-40.

Bond, D.R. and Lovley, D.R. (2003) 'Electric production by Geobacter sulfurreducens attached to electrodes', Appl. Environ. Microbiol., Vol. 69, pp.1548-1555.

Bond, D.R., Holmes, D.E., Tender, L.M. and Lovley, D.R. (2002) 'Electrode-reducing microorganisms that harvest energy from marine sediments', Science, Vol. 295, pp.483-485.

Chaudhuri, S.K. and Lovley, D.R. (2003) 'Electricity generation by direct oxidation of glucose in mediatorless microbial fuel cell', Nature Biotechnol., Vol. 21, pp.1229-1232.

Delaney, G.M., Bennetto, H.P., Mason, J.R., Roller S.D., Stirling J.L. and Thurston, C.F. (1984) 'Electron-transfer coupling in microbial fuel cells; 2. Performance of fuel cells containing selected microorganism-mediator-substrate combination', J. Chem. Tech. Biotechnol., Vol. 34B, pp.13-27.

Gil, G.C., Chang, I.S., Kim, B.H., Kim, M., Jang, J.K., Park, H.S. and Kim, H.J. (2003) 'Operational parameters affecting the performance of a mediator-less microbial fuel cell', Biosens. Bioelectron., Vol. 18, pp.327-334.

Hareland, W.A., Crawford, R.L., Chapman, P.J. and Dagley, S. (1975) 'Metabolic function and properties of 4-hydroxyphenylacetic acid 1-hydroxylase from Pseudomonas acidovorans', J. Bacteriol., Vol. 121, pp.272-285.

Kim, B.H., Ikeda, T., Park, H.S., Kim, H.J., Hyun, M.S., Kano, K., Takagi, K. and Tatsumi, H. (1999a) 'Electrochemical activity of an Fe(III)-reducing bacterium, Shewanella putrefaciens IR-1, in the presence of alternative electron acceptors', Biotechnol. Techniques, Vol. 13, pp. $475-478$. 
Kim, B.H., Kim, H.J., Hyun, M.S. and Park, D.H. (1999b) 'Direct electrode reaction of Fe(III)-reducing bacterium, Shewanella putrefaciens', J. Microbiol. Biotechnol., Vol. 9, No. 2, pp.127-131.

Kim, H.J., Hyun, M.S., Chang, I.S. and Kim, B.H. (1999c) 'A microbial fuel cell type lactate biosensor using a metal-reducing bacterium, Shewanella putrefaciens', J. Microbiol. Biotechnol., Vol. 9, No. 3, pp.365-367.

Kim, B.H., Park, D.H., Shin, P.K., Chang, I.S. and Kim, H.J. (1999d) Mediator-less biofuel cell, US Patent No. 5976719, US Patent and Trademark Office, Washington, DC, November.

Kim, H.J., Park, H.S., Hyun, M.S., Chang, I.S., Kim, M. and Kim, B.H. (2002) 'A mediator-less microbial fuel cell using a metal reducing bacterium, Shewanella putrefaciens', Enzyme Microb. Technol., Vol. 30, pp.145-152.

Liu, H. and Logan, B.E. (2004) 'Electric generation using an air-cathode single chamber microbial fuel cell in the presence and absence of a proton exchange membrane', Environ. Sci. Technol., Vol. 38, pp.4040-4046.

Liu, H., Ramnarayanan, R. and Logan, B.E. (2004) 'Production of electricity during wastewater treatment using a single chamber microbial fuel cell', Environ. Sci. Technol., Vol. 38, pp.2281-2285.

Logan, B.E., Murano, C., Scout, K., Gray, N.D. and Head, I.M. (2005) 'Electricity generation from cysteine in a microbial fuel cell', Water Research, Vol. 39, pp.942-952.

Min, B. and Logan, B.E. (2004) 'Continuous electricity generation from domestic wastewater and organic substrates in a flat plate microbial fuel cell', Environ. Sci. Technol., Vol. 38, pp.5809-5814.

Oh, S., Min, B. and Logan, B.E. (2004) 'Cathode performance as a factor in electricity generation in microbial fuel cells', Environ. Sci. Technol., Vol. 38, pp.4900-4904.

Park, D.H. and Zeikus J.G. (2003) Improved Fuel Cell and Electrode Designs for Producing Electricity From Microbial Degradation, www.interscience.wiley.com, DOI: 10.1002/ bit.10501 (Accessed December 2005).

Park, D.H. and Zeikus, J.G. (2000) 'Electricity generation in microbial fuel cells using neutral red as an electronophore', Appl. Environ. Microbiol., Vol. 66, pp.1292-1297.

Park, D.H. and Zeikus, J.G. (2002) 'Impact of electrode composition on electricity generation in single-compartment fuel cell using Shewanella putrifaciens', Appl. Microbiol. Biotechnol., Vol. 59, pp.58-61.

Videla, H.A. and Arvia, A.J. (1975) 'The response of a bioelectrochemical cell with Saccharomyces cerevisiae metabolizing glucose under various fermentation conditions', Biotechnol. Bioeng., Vol. 17, pp.1529-1543. 